\title{
NEW SPECIES OF DEMOSPONGIAE (PORIFERA) FROM THE NATIONAL PARK “ARCHIPIÉLAGO DE LOS ROQUES”, VENEZUELA*
}

\author{
by \\ M. CRISTINA DÍAZ, BELINDA ALVAREZ \\ Fundación Científica Los Roques, Apartado 1, Carmelitas, Caracas 1010 A, Venezuela \\ $\&$ \\ R. W. M. VAN SOEST \\ Institute of Taxonomic Zoology (Zoölogisch Museum), University of Amsterdam, \\ P.O. Box 20125, 1000 HC Amsterdam, the Netherlands
}

\begin{abstract}
Three new species of Demospongiae from coral reefs of the Archipiélago de Los Roques National Park (Venezuelan Caribbean) and Curaçao (Netherlands Antilles) are described, viz. Eurypon laughlini $\mathbf{n}$. sp., Topsentia roquensis $\mathbf{n}$. sp., and Epipolasis reiswigi n. sp. The new species and the genera to which they have been assigned are discussed, as a result of which the genus Fasubera De Laubenfels, 1936, is synonymized with Eurypon Gray, 1867, and the genus Epipolasis is redefined based on characters of its typespecies. Extensive ecological data are provided for each species.
\end{abstract}

\section{RESUMEN}

En este trabajo se describen tres especies nuevas de los arrecifes coralinos del Parque Nacional Archipiélago de Los Roques (Mar Caribe, Venezuela) y Curaçao: Eurypon laughlini n. sp., Topsentia roquensis n. sp., y Epipolasis reiswigi n. sp. Se discuten las nuevas especies y los géneros a los cuales han sido asignadas. Como resultado, el género Fasubera De Laubenfels, 1936 es sinonimizado con Eurypon Gray, 1867, y el género Epipolasis se redefine basándose en las características de su especie tipo. Se suministran datos ecológicos de cada una de las especies.

\section{INTRODUCTION}

An ecological study of the sponge community of a fringing coral reef at the Archipiélago de Los Roques National Park was carried out between January 1983 and August 1984 (Alvarez \&

* Scientific Contribution no. 23 of the Fundación Científica Los Roques.
Díaz, 1985). Sixty different demosponges were found, of which 33 were described. Three of these species appeared to be new to science. Taxonomic descriptions of the three species as well as additional ecological information are given in this paper.

\section{ACKNOWLEDGEMENTS}

We thank the staff of the Marine Station at Los Roques for assistance in this project, Ernesto Weil for the underwater photographs, the Laboratory of Photography of the Universidad Central de Venezuela for the photographic reproductions of the drawings and the specimens, and Dr. Roger Laughlin for his critical review of the manuscript and his constant encouragement and friendship. We are grateful to the members of the Fundación Científica Los Roques for logistic support.

\section{DESCRIPTION OF THE STUDY AREA}

The Archipiélago de Los Roques National Park is an insular reef complex located at about 150 $\mathrm{km}$ north of the north-central coast of Venezuela (fig. 1). It consists of 42 islands and more than 200 shoals and reefs, irregularly distributed around a shallow lagoon (depth 1-5 $\mathrm{m}$ ) in its centro-meridional portion.

The archipelago, or more precisely the semiatoll, rests on a submarine igneous plateau that rises sharply from depths of 900 to $1800 \mathrm{~m}$. The winds and oceanic currents are predominantly from the east-northeast. The climate in the islands can be classified as semi-arid with an average annual precipitation of $300 \mathrm{~mm}$. 


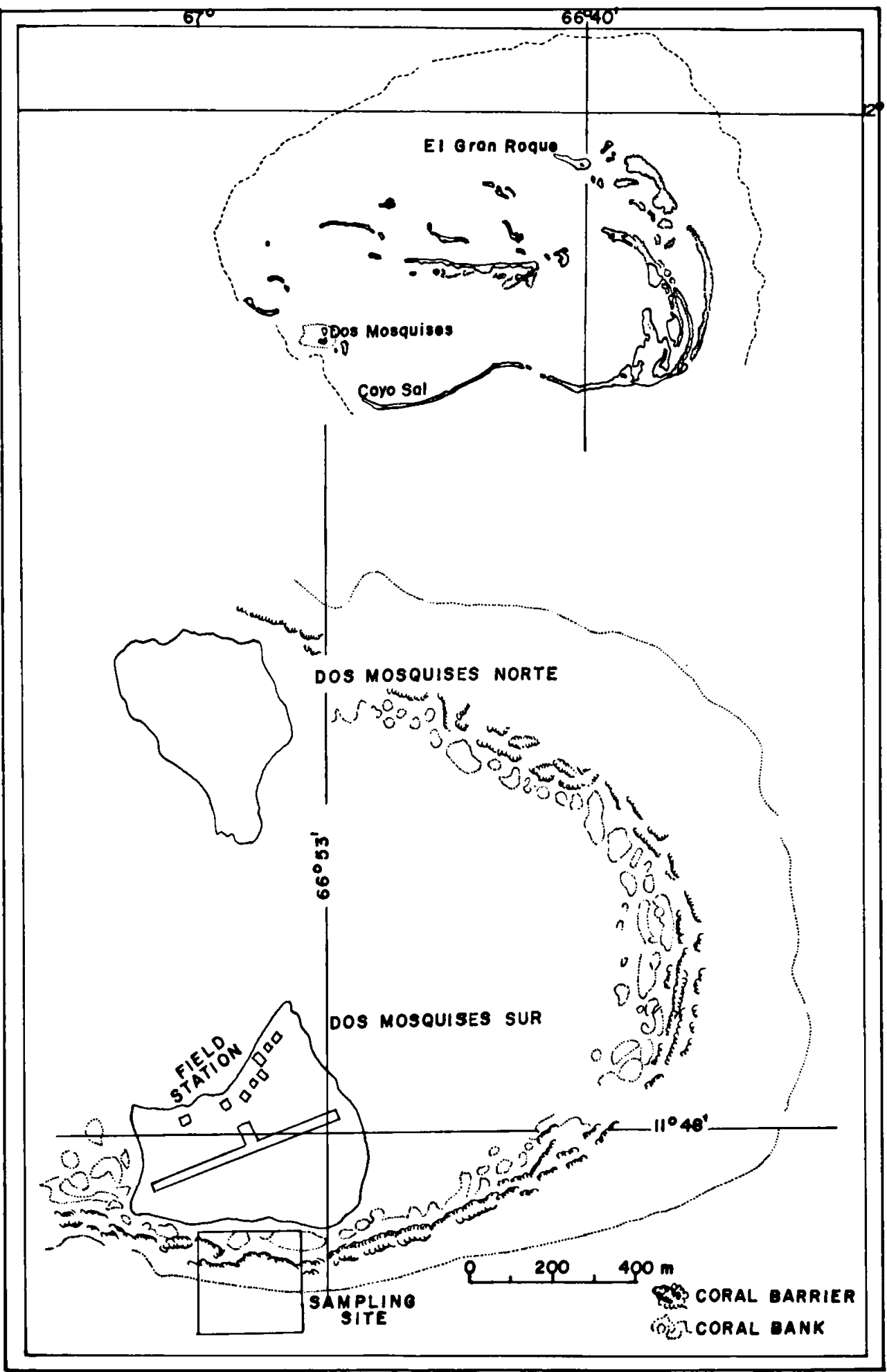

Fig. 1. The Archipiélago de Los Roques National Park (top), and the location of the sampling site (bottom). 
The fringing reef where the study was conducted is located south of the Dos Mosquises Sur Cay (fig. 1). It consists of a reef flat, a reef terrace and a drop-off which extends to a depth of $30 \mathrm{~m}$. The shallow reef flat $(0-2 \mathrm{~m})$ is dominated by the coral species Acropora palmata (Lamarck, 1816) and A. cervicornis (Lamarck, 1816); other species, viz. Madracis decactis (Lyman, 1859), Porites porites (Pallas, 1766), and Montastrea annularis (Ellis \& Solander, 1786) are also found dispersed among large extensions of dead coral fragments and sand. The reef terrace $(2-12 \mathrm{~m})$ is dominated by Montastrea annularis. The drop-off is characterized by an increased number of coral species although coral boulders are frequent. Below a depth of 28 $m$ sand is the main substrate.

Sponges are practically absent in open areas on the reef flat. They become abundant at depths below $8 \mathrm{~m}$ and constitute the most frequent and abundant group in deeper zones.

\section{MATERIAL AND METHODS}

Demosponges were collected with SCUBA equipment. Before collection, each individual was characterized in situ by its shape, colour, consistency, and other surface features. The height, cover, and oscule diameter of each specimen were also registered, as well as the substrate type where it was found, and the position occupied.

Once characterized, the sponge was photographed using a Nikonos IV underwater camera provided with a flash and a close-up unit. For taxonomic studies, parts of each specimen were fixed in a $10 \%$ formalin-seawater solution neutralized with borax, and then preserved in a $70 \%$ alcohol solution. Smaller parts of each sample were dried in the sun. The specimens are stored in the Fundación Científica Los Roques Museum in Caracas (FCLR) and in the Zoölogisch Museum, University of Amsterdam (ZMA). Spicule preparations were made by dissolving small fragments of the sponge in a boiling $20 \%$ potassium hydroxide solution. After disintegration of the soft component, a few drops of concentrated nitric acid were added to the preparation, which was then washed twice in distilled water and twice in $70 \%$ alcohol.

Length and width measurements of 25 spicules of each type were made for all specimens studied. Skeleton structure was determined from perpendicular and tangential hand sections (200-1000 $\mu \mathrm{m})$ cut with a razor blade, then treated with dioxane and transferred to distilled water for examination under a stereomicroscope.

Ecological parameters of the species such as distribution, frequency of occurrence, substrate area covered, and density on the reef were determined using a $1 \mathrm{~m}^{2}$ quadrat which was successively moved along a line transect. Five transects were sampled in total; transects were placed perpendicular to the shore and extended to depths of 28-35 m. Substrate cover was determined using a $50 \times 50 \mathrm{~cm}$ plastic frame subdivided in $13.7 \mathrm{~cm}^{2}$ meshes. Details of this methodology are given in Alvarez \& Díaz, 1985.

\section{SYSTEMATIC DESCRIPTIONS}

\section{Class Demospongiae \\ Order Axinellida \\ Family RaspailiIdaE \\ Genus Eurypon Gray, 1867}

\section{Eurypon laughlini n. sp.}

(Pl. I-A, fig. 2)

Material. - Holotype: Dos Mosquises Sur, Archipiélago de Los Roques National Park, Venezuela: on coral rock, depth $22 \mathrm{~m}$, 18.II.1983, coll. M. C. Díaz \& B. Alvarez (FCLR coll. no. Por. 110).

Paratypes: Dos Mosquises Sur, Archipiélago de Los RoQues: on coral rock, depth $7 \mathrm{~m}, 9 . \mathrm{XII} .83$, coll. M. C. Díaz \& B. Alvarez (FCLR coll. no. Por. 139); on coral rock, depth $15 \mathrm{~m}, 9$. XII.83, coll. M. C. Díaz \& B. Alvarez (FCLR coll. no. Por. A-25); on coral rock, depth $24 \mathrm{~m}$, 9.XII.83, coll. M. C. Díaz \& B. Alvarez (FCLR coll. no. Por. A-31); on coral rock, depth $15 \mathrm{~m}, 12 . \mathrm{X} .84$, coll. $\mathrm{M}$. C. Díaz \& B. Alvarez (FCLR coll. no. Por. A-41); on coral rock, depth $24 \mathrm{~m}, 13 . \mathrm{X} .84$, coll. M. C. Díaz \& B. Alvarez (FCLR coll. no. Por. A-43); on coral rock, depth $22 \mathrm{~m}$, 13.X.84, coll. M. C. Díaz \& B. Alvarez (FCLR coll. no. Por. A-45); on coral rock, depth $33 \mathrm{~m}, 13 . \mathrm{X} .84$, coll. M. C. Díaz \& B. Alvarez (FCLR coll. no. Por. A-46).

Curaçao: Cape Malmeeuw, on dead coral, depth 12-16 m, 23.XII.80, coll. R. W. M. van Soest (ZMA coll. no. Por. 5841); Awa Blancu, on dead coral, depth 10-20 m, 29.XII.80, coll. R. W. M. van Soest (ZMA coll. no. Por. 5842); Malmeeuw, on dead coral, depth $35 \mathrm{~m}$, IX.84, coll. W. Hoppe \& M. Reichert (ZMA coll. no. Por. 5706).

\section{Description}

Shape: A thin film over dead coral, elevation from the substrate up to $4 \mathrm{~mm}$.

Colour: Light orange in life; light brown in alcohol.

Consistency: Soft.

Surface: Optically smooth, but microscopically hispid, caused by the outward projection of single spicules (mainly tylostyles). Some specimens show coarse elevations made up by spicule tracts. 
Oscules: 1-6 mm in diameter, with a collar up to $5 \mathrm{~mm}$ in height. Difficult to observe in the field, generally contracted. In life, canals of 1-2 $\mathrm{mm}$ in width depart radially from the oscules.

Ectosome: Thin organic skin pierced by large spicules.

Choanosome: Dense. Skeleton formed by spicules, mainly tylostyles, disposed perpendicularly to the surface of attachment, with heads embedded in a thin spongin layer that constitutes the sponge base. Elevations formed by tracts of larger spicules directed outward. Large quantities of coral fragments of various sizes and many foreign spicules in the choanosome. Sponge tissue penetrating slightly the coral rock over which it grows.

Spicules: Tylostyles, size range $126-1855$ by 3-24 $\mu \mathrm{m}$. Individual sizes, means and standard deviations are given in table I. Some specimens with a great diversity and quantity of foreign spicules (oxea, strongyles, styles, cladotylotes, microstrongyles, spirasters, oxyasters, etc.).

Discussion. - The new species is an atypical Eurypon because of the absence of acanthostyles. De Laubenfels (1936) erected the genus Fasubera for the Indian Ocean species Hymedesmia lipochela Dendy, 1922, which like our new species conforms to the type-species of Eurypon (i.e. the European Hymeraphia clavata Bowerbank, 1866) in architecture and spicule form and sizes. We believe that the mere loss of acanthostyles does not represent a good synapomorphy and propose to abandon the use of Fasubera. De Laubenfels, 1954, assigned a second species to Fasubera, viz. F. debrumi, which does not seem to be related at all to lipochela and our new species. On the basis of De Laubenfels' description it could very well be assigned to Prosuberites Topsent, 1893 (order Hadromerida).

Several other species of Eurypon have been reported from the West Indian region: Eurypon clavatum sensu Topsent, 1889 and De Laubenfels, 1950 (probably not conspecific with the European species), Eurypon tourneti (Topsent, 1894, as Hymeraphia), Eurypon spec. bright yellow (Van Soest, 1981) and Eurypon spec. dark purple (Van Soest, 1981). All these

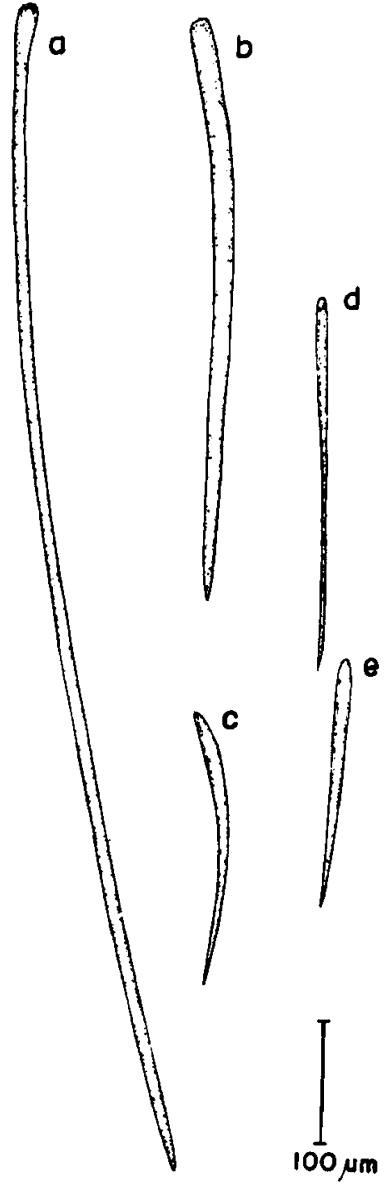

Fig. 2. Eurypon laughlini n. sp.: a-e, several size categories of tylostyles.

remain poorly known, but differ from our new species in having acanthostyles.

Etymology. - Named after Dr. R. Laughlin $G$. in recognition of his important contribution to the present study.

\section{Order HALICHONDRIDA}

Family HaLichondriddaE?

Genus Topsentia Berg, 1899

Topsentia roquensis $n$. $\mathrm{sp}$.

(Pl. I-B \& C, fig. 3)

Material. - Holotype: Dos Mosquises Sur, Archipiélago de Los RoQues National Park, Venezuela: on coral rock, depth $28 \mathrm{~m}, 29$. III.83, coll. M. C. Díaz \& B. Alvarez (FCLR coll. no. Por. 125). 
TABLE I

Eurypon laughlini n. so.: Means $(X)$. standard deviations (S.D.) and ranges of length and width of tylostyles and the diameter of tylostyle heads in individual specimens (all data in $\mu \mathrm{m}$ ).

\begin{tabular}{lccccc}
\hline Coll. no. & $\bar{X}$ & S.D. & Min. & Max. & $N$ \\
\hline Tylostyles & & & & & \\
FCLR Por. 110 & $285.4 \times 10.5$ & $132.9 \times 3.2$ & $126 \times 3$ & $559 \times 18$ & 25 \\
FCLR Por. 139 & $407.4 \times 10.8$ & $212.3 \times 3.1$ & $171 \times 6$ & $1040 \times 15$ & 40 \\
FCLR Por. A-25 & $479.4 \times 13.9$ & $215.8 \times 4.4$ & $260 \times 9$ & $1209 \times 24$ & 25 \\
FCLR Por. A-31 & $531.3 \times 8.6$ & $278.5 \times 2.6$ & $208 \times 3$ & $1300 \times 12$ & 25 \\
FCLR Por. A-41 & $462.9 \times 10.9$ & $170.6 \times 4.4$ & $182 \times 6$ & $1495 \times 21$ & 30 \\
FCLR Por. A-43 & $523.5 \times 10.1$ & $303.7 \times 2.6$ & $260 \times 6$ & $1430 \times 15$ & 30 \\
FCLR Por. A-45 & $574.2 \times 9.7$ & $375.5 \times 4.0$ & $260 \times 3$ & $1677 \times 18$ & 30 \\
FCLR Por. A-46 & $496.6 \times 12.3$ & $190.7 \times 3.9$ & $234 \times 6$ & $832 \times 21$ & 30 \\
ZMA Por. 5706 & $679.5 \times 11.0$ & $442.9 \times 5.2$ & $232 \times 4$ & $1245 \times 18$ & 10 \\
ZMA Por. 5841 & $638.2 \times 11.8$ & $389.4 \times 3.7$ & $209 \times 8$ & $1130 \times 15$ & 10 \\
ZMA Por. 5842 & $1177.4 \times 13.4$ & $740.7 \times 4.3$ & $202 \times 6$ & $1855 \times 16$ & 10 \\
Diameter of tylostyle heads & & & & & \\
FCLR Por. 139 & 16.9 & 4.4 & 9 & 24 & 28 \\
FCLR Por. A-25 & 19.8 & 5.1 & 12 & 28 & 25 \\
FCLR Por. A-41 & 16.4 & 3.4 & 9 & 21 & 30 \\
FCLR Por. A-43 & 15.1 & 2.8 & 12 & 21 & 30 \\
FCLR Por. A-45 & 16.1 & 3.8 & 9 & 21 & 25 \\
FCLR Por. A-46 & 18.2 & 5.1 & 9 & 27 & 30 \\
ZMA Por. 5706 & 16.8 & 4.5 & 13 & 23 & 10 \\
ZMA Por. 5841 & 15.2 & 4.8 & 15 & 21 & 10 \\
ZMA Por. 5842 & 19.2 & 3.6 & & 23 & 10 \\
\hline
\end{tabular}

Paratypes: Dos Mosquises Sur, Archipiélago de Los RoQues: on coral rock, depth $29 \mathrm{~m}, 10 . \mathrm{XII} .83$, coll. $\mathrm{M}$. C. Díaz \& B. Alvarez (FCLR coll. no. Por. A-35); on coral rock, depth $25 \mathrm{~m}, 13$. X.84, coll. M. C. Díaz \& B. Alvarez (FCLR coll. no. Por. A-49).

Curaçao: Playa Kalki, depth 10-20 m, 30.XII.80, coll. R. W. M. van Soest (ZMA coll. no. Por. 5840); buoy 2, $500 \mathrm{~m} \mathrm{~W}$. of Piscadera Bay, depth $10 \mathrm{~m}, 2 . \mathrm{I} .81$, coll. R. W. M. van Soest (ZMA coll. no. Por. 5839).

\section{Description}

Shape: Massive-amorphous, sometimes forming lobes or upright plates. May reach heights of up to $27 \mathrm{~cm}$. In some specimens there are several sharply pointed elevations at the top, irregularly distributed, with heights of $2-8 \mathrm{~cm}$.

Colour: Rose-purple with brownish tinges in life. Light beige in alcohol. Walnut-brown in dry condition.

Consistency: Hard as a rock but brittle when cut. In dry condition it becomes less brittle.
Surface: Smooth, but rough to the touch. Yellowish coloured zoanthids (probably Parazoanthus swiftii Duchassaing \& Michelotti, 1860) growing over almost all specimens.

Oscules: Little evident in most specimens. In some cases irregular pores, $3-5 \mathrm{~mm}$ in diameter, occur on the surface. Only one of the specimens observed had the oscules aggregated on top of the lobes (pl. I-C).

Ectosome: Not detachable. Skeleton formed by spicules arranged paratangentially and disorderly.

Choanosome: Light beige in life. Skeleton formed by spicules arranged disorderly. As in the ectosome, a skeletal organization is not evident.

Spicules: Hastate oxea of three size classes: $108-304$ by $3-12 \mu \mathrm{m}, 312-546$ by $3-18 \mu \mathrm{m}$ and $559-975$ by $12-36 \mu \mathrm{m}$ (for means and standard deviations see table II). Some fusiform and hastate styles are found in low frequency. 


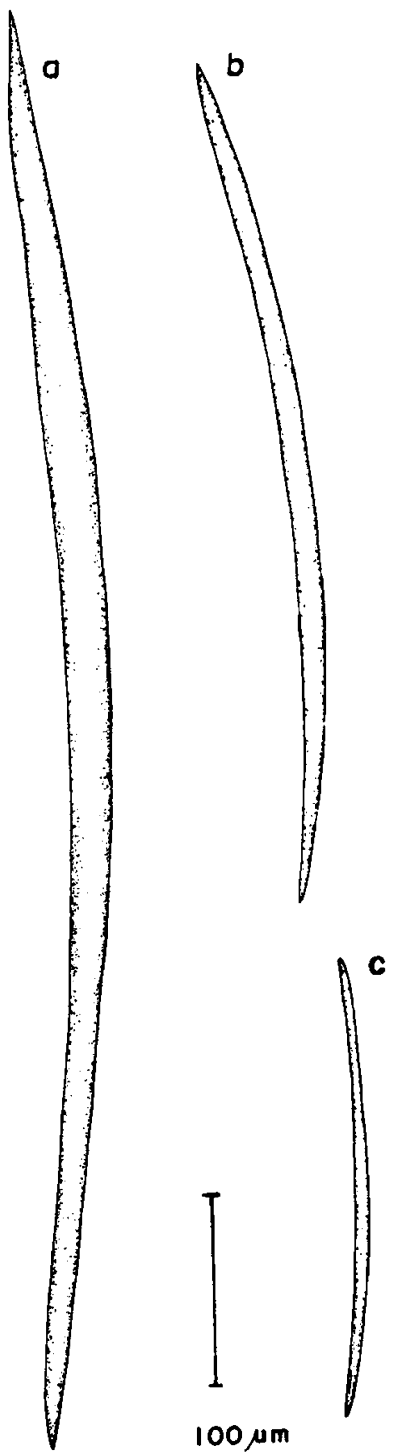

Fig. 3. Topsentia roquensis $\mathrm{n}$. sp.: a-c, three categories of oxea.

Discussion. - Up to now only one West Indian species has been formally described in the genus Topsentia, viz. the orange $T$. gyroderma Alcolado, 1984; this is a suspect assignment, because the surface characteristics of this sponge remind more of Myrmekioderma, Didiscus and Epipolasis (see below) than of Topsentia. The tantalizingly short description and barely discernible photographic representation make further comparisons impossible. Van Soest (1981) listed a Topsentia with "purple digita- tions" which might prove to be another West Indian species. Furthermore, the black Epipolasis lithophaga Wiedenmayer, 1977, possibly constitutes a third West Indian Topsentia, at least it cannot be maintained in the genus Epipolasis (see below). Aponastra modesta Pulitzer-Finali, 1986, from Jamaica, needs comparison with Topsentia because the "microrhabds" described in this species might be homologous with the smallest category of oxea found in most Topsentia species. Halichondria lutea Alcolado, 1984 also needs to be compared with Topsentia, on account of the great size range given for the oxea. Finally, the West African Topsentia porrecta (Topsent, 1928, as Coelocalypta) is known to occur in deep water near Barbados (Van Soest, in preparation); it differs from the present new species in habit (fistulose) and consistency (more fragile).

Topsentia shows affinities with Spongosorites Topsent, 1896 (possessing crooked oxea) and Amorphinopsis Carter, 1876 (possessing a mixture of oxea and styles) by the size categories found in the spicules, and also by the often twice-curved nature of some of the oxea. Other genera are certainly (Coelocalypta) or likely (Laminospongia Pulitzer-Finali, 1983) synonymous with Topsentia.

\section{Genus Epipolasis De Laubenfels, 1936}

Epipolasis reiswigi n. sp.

(Pl. I-D, fig. 4)

Material. - Holotype: Dos Mosquises Sur, Archipiélago de Los Roques National Park, Venezuela: on sand with coral fragments, depth $30 \mathrm{~m}, 20 . \mathrm{I} .83$, coll. M. C. Díaz B. Alvarez (FCLR coll. no. Por. 68).

Paratypes: Dos Mosquises Sur, Archipiélago de Los Roques: on coral rock, depth $30 \mathrm{~m}, 9$. XII.83, coll. M. C. Díaz \& B. Alvarez (FCLR coll. no. Por. A-18); on coral rock, depth $32 \mathrm{~m}, 9 . \mathrm{XII} .83$, coll. M. C. Díaz \& B. Alvarez (FCLR coll. no. Por. A-37); on sand with coral fragments, depth $28 \mathrm{~m}, 13 . \mathrm{X} .84$, coll. M. C. Díaz B. Alvarez (FCLR coll. no. Por. A-47).

\section{Description}

Shape: Massive-amorphous, with lobes on which the oscules are located. Some specimens 
TABLE II

Topsentia roquensis $\mathrm{n}$. sp.: Means $(\bar{X})$, standard deviations (S.D.) and ranges of three size categories of spicules in individual specimens (all data in $\mu \mathrm{m}$ ).

\begin{tabular}{lccccc}
\hline Coll. no. & $\bar{X}$ & S.D. & Min. & Max. & $N$ \\
\hline Small oxea & & & & & \\
FCLR Por. 125 & $248.9 \times 8.0$ & $24.3 \times 2.1$ & $189 \times 6$ & $300 \times 12$ & 23 \\
FCLR Por. A-35 & $195.2 \times 7.6$ & $40.7 \times 2.8$ & $108 \times 3$ & $273 \times 12$ & 25 \\
FCLR Por. A-49 & $199.4 \times 7.1$ & $49.1 \times 2.7$ & $123 \times 3$ & $300 \times 12$ & 25 \\
ZMA Por. 5839 & $235.0 \times 6.4$ & $53.7 \times 1.7$ & $109 \times 4$ & $304 \times 8$ & 10 \\
ZMA Por. 5840 & $197.4 \times 5.7$ & $33.3 \times 1.0$ & $145 \times 5$ & $226 \times 7$ & 10 \\
Medium oxea & & & & & \\
FCLR Por. 125 & $431.6 \times 10.0$ & $50.5 \times 2.5$ & $338 \times 6$ & $520 \times 12$ & 25 \\
FCLR Por. A-35 & $391.1 \times 11.9$ & $71.5 \times 2.4$ & $312 \times 9$ & $546 \times 18$ & 24 \\
FCLR Por. A-49 & $406.4 \times 14.1$ & $59.2 \times 5.0$ & $325 \times 3$ & $507 \times 18$ & 25 \\
ZMA Por. 5839 & $421.5 \times 11.0$ & $41.8 \times 1.4$ & $385 \times 9$ & $481 \times 12$ & 10 \\
ZMA Por. 5840 & $420.3 \times 10.8$ & $82.3 \times 1.7$ & $346 \times 9$ & $530 \times 13$ & 10 \\
Large oxea & & & & & \\
FCLR Por. 125 & $682.0 \times 20.9$ & $77.0 \times 4.7$ & $559 \times 12$ & $845 \times 27$ & 25 \\
FCLR Por. A-35 & $675.4 \times 19.4$ & $80.6 \times 4.3$ & $559 \times 12$ & $845 \times 27$ & 25 \\
FCLR Por. A-49 & $689.0 \times 21.8$ & $96.1 \times 7.3$ & $559 \times 12$ & $975 \times 36$ & 25 \\
ZMA Por. 5839 & $727.0 \times 21.2$ & $106.3 \times 3.6$ & $575 \times 16$ & $845 \times 26$ & 10 \\
ZMA Por. 5840 & $770.1 \times 26.7$ & $47.6 \times 1.1$ & $700 \times 25$ & $825 \times 28$ & 10 \\
\hline
\end{tabular}

with thick and amorphous branches rising up to $10 \mathrm{~cm}$ over the substrate. Channeled depressions ( $5 \mathrm{~mm}$ in diameter), of diverse length and shape, located on the surface.

Colour: In life, bright orange in depressions and choanosome; due to the presence of epiphytes and sand on the sponge surface it presents a grey colour. In alcohol between greyish and beige. In dry condition, the choanosome and depressions have a walnutbrown colour, while the elevations turn to a beige colour. The specimens exude an orange substance and expel a disagreeable odour.

Consistency: In life slightly compressible. In dry condition it turns hard.

Surface: Due to the large quantity of sediment over the surface it is difficult to judge the texture. Channeled depressions are smooth.

Ectosome: In many specimens the channeled depressions are covered by a fine skin that tears easily. In elevations the ectosome presents a layer of tissue with accumulation of spicules tangentially arranged; the largest spicule category occurs in low frequency in that layer.
Choanosome: Cavernous, with canals of 1$8.4 \mathrm{~mm}$ in diameter. Skeleton formed by vague spicule tracts $(120-280 \mu \mathrm{m}$ in diameter) disorderly arranged, which may run obliquely or parallel to the surface; in some areas the skeleton is formed by a mass of spicules.

Spicules: Two size classes of hastate-fusiform oxea and one of small fusiform oxea: $390-910$ by $15-36 \mu \mathrm{m}, 182-520$ by $3-20 \mu \mathrm{m}$, and $84-416$ by $3-12 \mu \mathrm{m}$; microscleres abundant, curved or vermiform trichodragmata: $80-102$ by $3-8.5$ $\mu \mathrm{m}$. Means and standard deviations of spicule sizes are given in table III.

Discussion. - The new species is close to the type-species of Epipolasis, i.e. the Indo-West Pacific Spongosorites suluensis Wilson, 1925. It shares the surface peculiarities and the vermiform trichodragmata, while spicule sizes are comparable. E. suluensis differs in details of the channeled depressions and in life colour which appears to be rosy-red (based on recent observations of the species in Indonesian waters). 

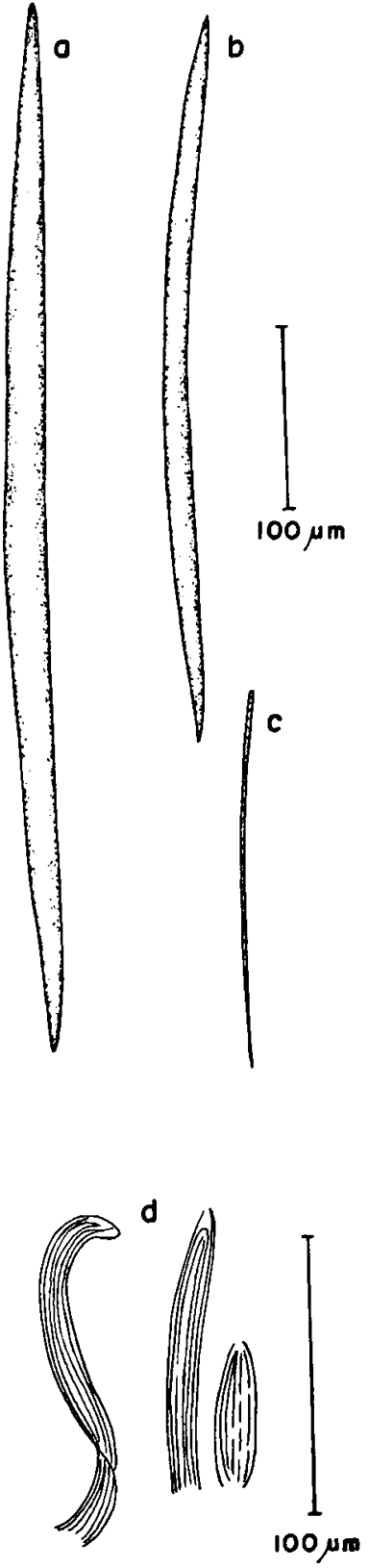

Fig. 4. Epipolasis reiswigi n. sp.: a, hastate oxea; b, hastate to fusiform oxea; c, fusiform oxea; $d$, curved and vermiform trichodragmata (a, b, and c drawn to the same scale figured above; d drawn to scale figured below).

The genus Epipolasis is here employed for sponges similar to the type-species. De Laubenfels (1936) included in the original concept of the genus also Suberites angulospiculatus Carter, 1882, but this is now known to be a senior synonym of Roosa zyggompha and belongs to the genus Plakortis (order Homosclerophorida) (checked against Carter's typespecimen in the British Museum (Natural History). Wiedenmayer, 1977 was not aware of De Laubenfels' misinterpretation of the typespecies of his new genus Epipolasis, which is apparent from Wiedenmayer's discussion of the genus, and also from the assignment of his lithophaga to this genus. Because this species has no vermiform trichodragmata it probably belongs to Topsentia.

The genus name Raspaigella Schmidt, 1868 has been employed for sponges having the characteristics of Epipolasis (see Burton, 1959, and Vacelet et al., 1976). The justification for this is not clear: there is nothing in Schmidt's description of the genus or the type-species $R$. brunnea suggesting that trichodragmata are present. There are no recent redescriptions of original material or fresh specimens of $R$. brunnea.

Genera close to Epipolasis are Myrmekioderma Ehlers, 1870 (cf. discussions in Bergquist, 1965), and Didiscus Dendy, 1922. Both genera have a wide size range of oxeote megascleres and channeled surface depressions comparable to those of E. reiswigi n. sp. Likewise, Topsentia gyroderma Alcolado, 1984, has these depressions, judging from the bad photograph of the typespecimen. Myrmekioderma (with West Indian representative $M$. styx De Laubenfels, 1953) has the smaller category of oxea lightly spined and curved trichodragmata are present. Didiscus (with West Indian representative $D$. oxeata Hechtel, 1983, senior synonym of $D$. flavus Van Soest, 1984 and D. habanensis Alcolado, 1984) has very characteristic discorhabds. The generic assignment of Topsentia gyroderma cannot at present be evaluated. It is clear that this group of closely related genera is in urgent need of revision, which will quite likely result in a reduction of the number of generic names.

Etymology. - Named after Dr. Henry Reiswig in recognition of his important contributions to our knowledge of sponge biology. 
TABLE III

Epipolasis reiswigi n. sD.: Means ( $X$ ). standard deviations (S.D.) and ranges of three size categories of megascleres and of trichodragmata in individual specimens (all data in $\mu \mathrm{m}$ ).

\begin{tabular}{|c|c|c|c|c|c|}
\hline Coll. no. & $\bar{X}$ & S.D. & Min. & Max. & $N$ \\
\hline \multicolumn{6}{|l|}{ Hastate oxea } \\
\hline FCLR Por. 68 & $819.5 \times 28.2$ & $66.9 \times 4.9$ & $624 \times 15$ & $910 \times 36$ & 25 \\
\hline FGLR Por. A-18 & $808.6 \times 26.9$ & $80.8 \times 3.1$ & $520 \times 18$ & $910 \times 30$ & 25 \\
\hline FCLR Por. A-37 & $782.1 \times 24.8$ & $46.2 \times 2.7$ & $650 \times 21$ & $832 \times 30$ & 25 \\
\hline FCLR Por. A-47 & $755.6 \times 27.7$ & $162.8 \times 3.9$ & $390 \times 21$ & $910 \times 36$ & 25 \\
\hline \multicolumn{6}{|c|}{ Hastate to fusiform oxea } \\
\hline FCLR Por. 68 & $410.8 \times 11.1$ & $97.4 \times 2.7$ & $286 \times 6$ & $520 \times 20$ & 40 \\
\hline FCLR Por. A-18 & $406.6 \times 12.0$ & $64.8 \times 2.6$ & $182 \times 3$ & $520 \times 15$ & 25 \\
\hline FCLR Por. A-37 & $408.7 \times 11.2$ & $48.1 \times 1.8$ & $312 \times 9$ & $520 \times 15$ & 25 \\
\hline FCLR Por. A-47 & $341.1 \times 10.1$ & $36.1 \times 2.4$ & $260 \times 6$ & $403 \times 12$ & 25 \\
\hline \multicolumn{6}{|l|}{ Fusiform oxea } \\
\hline FCLR Por. 68 & $238.0 \times 3.0$ & $35.7 \times 0$ & $182 \times 3$ & $328 \times 3$ & 23 \\
\hline FCLR Por. A-18 & $225.9 \times-$ & $120.8 \times-$ & $84 x-$ & $416 \times 12$ & 40 \\
\hline FCLR Por. A-37 & $234.4 \times 3.0$ & $52.3 \times 0$ & $104 \times 3$ & $312 \times 3$ & 25 \\
\hline FCLR Por. A-47 & $250.3 \times 3.3$ & $54.3 \times 0.9$ & $117 \times 3$ & $325 \times 6$ & 12 \\
\hline \multicolumn{6}{|l|}{ Trichodragmata } \\
\hline Various specimens & $91.7 \times 6.2$ & $10.4 \times 2.8$ & $80 \times 3$ & $102 \times 8.5$ & 25 \\
\hline
\end{tabular}

\section{ECOLOGICAL REMARKS}

In the reef studied at Los Roques, demosponges are well represented in species number (higher than that of scleractinian corals, see Hung, 1985). Analysis of community structure (richness, density, cover, diversity) shows a tendency towards increase of complexity with depth. The evenness values, however, are more or less comparable along the depth profile (Díaz, Alvarez \& Laughlin, in preparation). According to these results, the three new species described in the present paper are among the 27 species that constitute $95 \%$ of the area covered and of the total number of individuals. Important ecological remarks on the three new species are given below:

\section{Eurypon laughlini $\mathrm{n}$. sp.}

Frequent species, with a wide depth range (3-35 $\mathrm{m})$. Relatively higher values of area covered and density (number of individuals $/ \mathrm{m}^{2}$ ) were registered toward the deeper zones of the reef. However, the mean area covered per individual $\left(23 \mathrm{~cm}^{2}\right.$, S.D. $\left.=25.4, n=100\right)$ and area covered per $\mathrm{m}^{2}\left(31.6 \mathrm{~cm}^{2}\right.$, S.D. $\left.=29.6, n=76\right)$ were relatively low. Nevertheless, because this species grows in cryptic areas, it is believed that the values of area covered were underestimated. The density of this species was relatively low with maximum values of 3 individuals per $\mathrm{m}^{2}$. Usually it grows over coral rock.

2. Topsentia roquensis $\mathrm{n}$. $\mathrm{sp}$.

Restricted to the deep zone of the reef (23-30 $\mathrm{m})$. It showed one of the highest mean values of area covered per individual $\left(166.4 \mathrm{~cm}^{2}\right.$, S.D. $=144.6, n=6)$ and area covered per $\mathrm{m}^{2}$ $\left(166.1 \mathrm{~cm}^{2}\right.$, S.D. $\left.=144.6, n=6\right)$. Nevertheless, the density was never greater than 1 individual per $\mathrm{m}^{2}$. The specimens usually grow over coral rocks.

3. Epipolasis reiswigi n. sp.

A common species found between $13-30 \mathrm{~m}$. High frequency and abundance values were registered below a depth of $20 \mathrm{~m}$. The mean values of area covered per individual and area 
covered per $\mathrm{m}^{2}\left(76.5 \mathrm{~cm}^{2}, \mathrm{~S} . \mathrm{D} .=49.4, n=12\right.$; $72.5 \mathrm{~cm}^{2}$, S.D. $\left.=45.7, n=12\right)$ are intermediate. Density is never greater than 1 individual $/ \mathrm{m}^{2}$. It typically grows on sandy substrates, and it is usually found covered almost completely by sand.

\section{LITERATURE CITED}

Alcolado, P. M., 1984. Nuevas especies de esponjas encontradas en Cuba. Poeyana, 271: 1-22.

Alvarez, M. B. \& M. C. Díaz, 1985. Las esponjas de un arrecife coralino en el Parque Nacional Archipiélago de Los Roques. I, Taxonomía. II, Estructura ecológica: 1-216 (Tesis de Licenciatura, Universidad Central de Venezuela, Facultad de Ciencias, Escuela de Biología, Caracas).

Bergquist, P. R., 1965. The sponges of Micronesia, I. The Palau Archipelago. Pacif. Sci., 19 (2): 123-204.

Burton, M., 1959. Sponges. Scient. Rep. John Murray Exped., 10 (5): 151-281.

Dendy, A., 1922. Report on the Sigmatotetraxonida collected by H.M.S. "Sealark" in the Indian Ocean. Trans. Linn. Soc. Lond., (2, Zool.) 18: 1-164.

Hechtel, G., 1983. New species of marine Demospongiae from Brazil. Iheringia, (Zool.) 63: 59-89.

Hung, M., 1985. Los corales pétreos del Parque Nacional Archipiélago de Los Roques: 1-216 (Tesis de Licenciatura, Universidad Central de Venezuela, Facultad de Ciencias, Escuela de Biología, Caracas).

Laubenfels, M. W. DE, 1936. A discussion of the sponge fauna of the Dry Tortugas in particular, and the West Indies in general, with materials for a revision of the families and orders of the Porifera. Pap. Tortugas Lab., 30: 1-225.

-, 1950 . The Porifera of the Bermuda Archipelago. Trans. zool. Soc. Lond., 27: 1-154.

- - 1953. Sponges from the Gulf of Mexico. Bull. mar. Sci. Gulf Caribb., 2: 511-557.

-, 1954. The sponges of the West Central Pacific.
Oregon State Monogr. Stud. Zool., 7: i-x, 1-306.

Pulitzer-Finali, G., 1983. A collection of Mediterranean Demospongiae (Porifera) with in appendix a list of Demospongiae hitherto recorded from the Mediterranean Sea. Annali Mus. civ. Stor. nat. Giacomo Doria, 84: 445-661.

- - 1986. A collection of Demospongiae from the West Indies with in appendix a list of the Demospongiae hitherto recorded from the West Indies. Annali Mus. civ. Stor. nat. Giacomo Doria, 86: 1-216.

Sснмidt, O., 1868. Die Spongien der Küste von Algier. Mit Nachträgen zu den Spongien des Adriatischen Meeres (Drittes Supplement): i-iv, 1-44 (Engelmann, Leipzig).

Soest, R. W. M. VAN, 1981. A checklist of Curaçao sponges (Porifera: Demospongiae). Verslagen en technische Gegevens, Inst. taxon. Zoöl. (Zoöl. Mus.), Univ. Amsterdam, 32: 1-33.

--, 1984. Marine sponges from Curaçao and other Caribbean localities, III. Poecilosclerida. Stud. Fauna Curaçao, 66: 1-167.

Topsent, É., 1889. Quelques Spongiaires du Banc de Campêche et de la Pointe-à-Pître. Mém. Soc. zool. Fr., 2: 30-52.

- - 1894. Application de la taxonomie actuelle à une collection de Spongiaires du Banc de Campêche et de la Guadeloupe décrite précédemment. Mém. Soc. zool. Fr., 7: 27-36.

- - 1928. Spongiaires de l'Atlantique et de la Méditerranée, provenant des croisières du Prince Albert 1er de Monaco. Résult. Camp. scient. Prince Albert 1, 74: i-iii, 1-376, [377-399], pls. I-XI.

Vacelet, J., P. Vasseur \& C. Levi, 1976. Spongiaires de la pente externe des récifs coralliens de Tuléar (sudouest Madagascar). Mém. Mus. natn. Hist. nat. Paris, (N.S.) A (Zool.) 99: 1-116.

Wiedenmayer, F., 1977. A monograph of the shallowwater sponges of the western Bahamas: 1-287 (Birkhäuser Verlag, Basel \& Stuttgart).

Wilson, H. V., 1925. Siliceous and horny sponges collected by the U.S. Fisheries steamer "Albatross" during the Philippine Expedition, 1907-10. Bull. U.S. natn. Mus., 100 (2, 4): i-vii, 273-532.

Second draft received: 9 June 1986

\section{Plate I}

Fig. A. Eurypon laughlini n. sp., holotype (FCLR coll. no. Por. 110) from a fringing coral reef at Dos Mosquises Sur Cay. Archipiélago de Los Roques National Park, photographed in situ (photo E. Weil).

Fig. B. Topsentia roquensis n. sp., holotype (FCLR coll. no. Por. 125) from a fringing coral reef at Dos Mosquises Sur Cay, Archipiélago de Los Roques National Park, photographed in situ (photo E. Weil).

Fig. C. Topsentia roquensis n. sp., elevated oscules in another specimen from the same area, photographed in situ (photo E. Weil).

Fig. D. Epipolasis reiswigi n. sp., holotype (FCLR coll. no. Por. 68) from a fringing coral reef at Dos Mosquises Sur Cay, Archipiélago de Los Roques National Park, photographed in situ (photo E. Weil). 

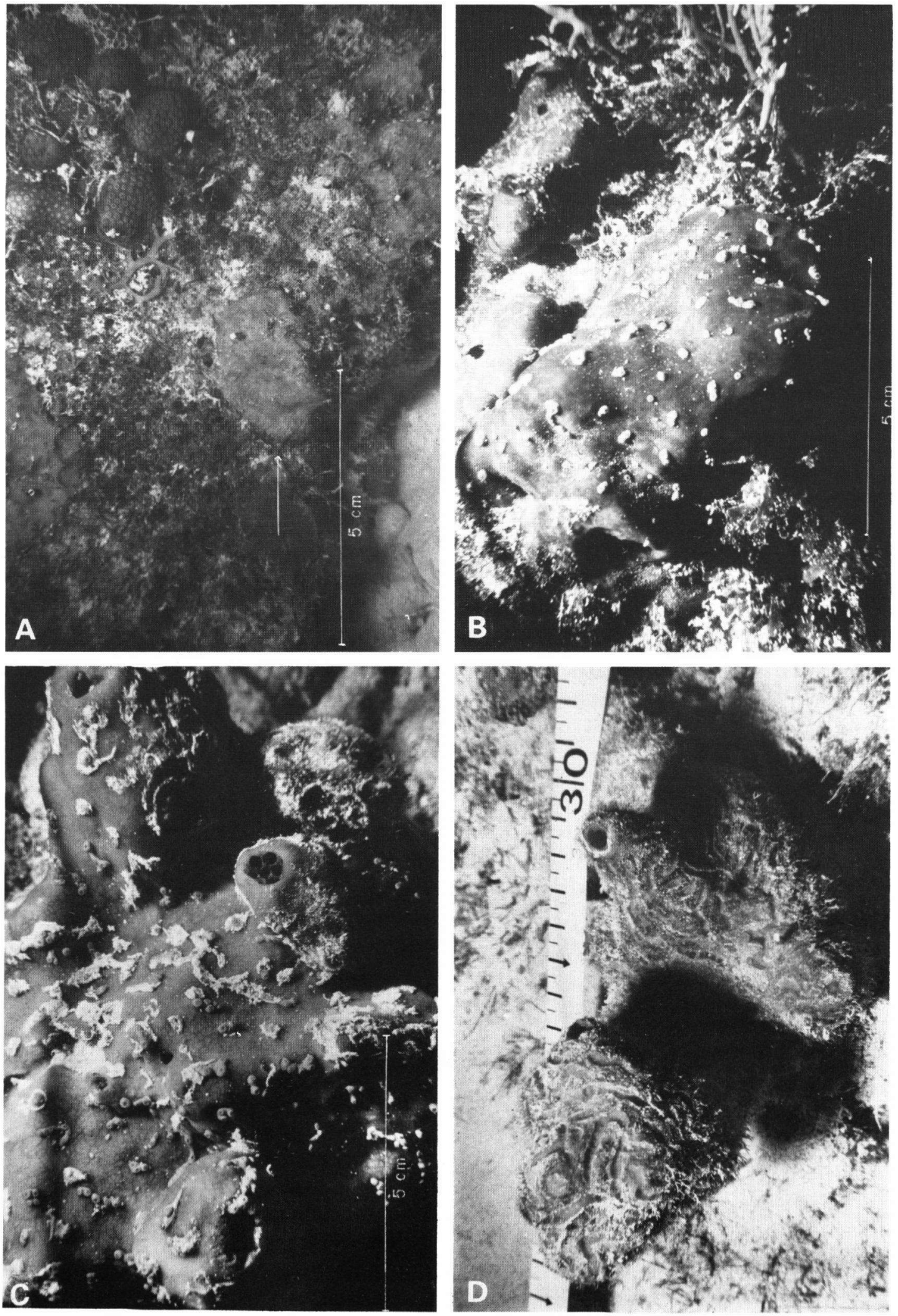

Plate I 